\title{
Meetings Calendar
}

\section{Presenting upcoming meetings and calls for papers}

Symposia Proposals and Abstract Submissions: For TMS-sponsored meetings, symposia proposals and abstracts must be submitted through ProgramMaster, the on-line TMS conference and proceedings management system. The system can be accessed at www.tms.org. Using the Meetings \& Events pulldown menu, select the Upcoming TMS Meeting for which you wish to submit a symposia proposal or an abstract, and follow the on-line instructions. The society especially encourages the submission of "hot-topic" symposia or special-session proposals on timely or developing subjects. To advance an idea, use the symposium creation form in ProgramMaster. Additional information can be acquired from the TMS Technical Support Services Department, 184 Thorn Hill Road, Warrendale, PA 15086; (724) 776-9000, ext. 212; fax (724) 776-3770.

\section{TMS Annual and Specialty Meetings}

\section{TMS 2012 Annual Meeting}

March 11-15, 2012

Orlando, Florida

This meeting is the premier TMS event, featuring more than 60 symposia sponsored by all five TMS technical divisions on the latest scientific and technical developments. Technical programming will be focused on the following themes: Advanced Characterization, Modeling and Materials Performance; High Performance Materials; Light Metals: Aluminum, Magnesium, and Titanium; Materials and Society: Energy and Sustainable Production; Materials Processing and Production; and Nanoscale and Amorphous Materials. This $141^{\text {st }}$ meeting will also feature a large exhibition, short courses, tutorial lectures, award presentations, receptions and division luncheons, invited speakers, and student activities. The location for this year's event is the Walt Disney World Swan and Dolphin Resort. Contact: Meeting Services; TMS 184 Thorn Hill Road, Warrendale, PA 15086; Phone: (724) 776-9000, ext. 243; Fax: (724) 776-3770; e-mail mtgserv@ tms.org; www.tms.org/meetings/annual-12 /AM12home.aspx.

\section{ICAA-13}

June 3-7, 2012

Pittsburgh, Pennsylvania

The 13th International Conference on Aluminum Alloys (ICAA-13) is coming to Carnegie Mellon University in Pittsburgh, Pennsylvania - the birthplace of the modern aluminum industry. The conference will include the following topics: the science of aluminum alloy design for a range of market applications, accurate prediction of materials properties, novel aluminum products and processes, and emerging developments in recycling and applications. Contact: Meeting Services, TMS, 184 Thorn Hill Road, Warrendale, PA 15086; (724) 776-9000, ext. 243; fax: (724) 776-3770; e-mail:mtgserv@tms.org;www.tms.org /Meetings/Specialty/ICAA13/home.aspx.

\section{D Materials Science 2012}

$$
\text { July 8-12, } 2012
$$

\section{Seven Springs, Pennsylvania}

The International Conference on 3D Materials Science seeks to provide the premier forum for presentations on the three dimensional characterization, visualization, quantitative analysis, modeling, and investigation of structure-property relationships of materials. This conference will also provide an environment for rich discussions and interactions amongst the key researchers to not only assess the state-of-the-art within the various elements of $3 \mathrm{D}$ materials science, but to roadmap the key areas of future research. Contact: Meeting Services, TMS, 184 Thorn Hill Road, Warrendale, PA 15086 USA; (724) 776-9000, ext. 243; fax: (724) 776-3770; e-mail: mtgserv@tms.org; www .tms.org/Meetings/Specialty/3D2012/home. aspx.

\section{Superalloys 2012 September 9-13, 2012 \\ Champion, Pennsylvania}

The purpose of this Twelfth International Symposium on Superalloys is to provide a forum for researchers, producers, and users to present the most recent technical information on a class of high-strength, high-temperature alloys commonly known as superalloys. The overall scope seeks to highlight advances in superalloys made possible by practical application of modeling and simulation. The technical focus will be on alloy development, processing, coatings and environmental effects, and mechanical behavior, with an increased focus on how modeling tools were developed and applied in these areas. Contact: Meeting Services, TMS, 184 Thorn Hill Road, Warrendale, PA 15086; (724) 776-9000, ext. 243; e-mail mtgserv@tms.org; www.tms.org/Meetings /Specialty/Superalloys2012/home.aspx.

\section{PRICM-8 \\ August 4-9, 2013 \\ Waikoloa, Hawaii}

Held every three years, this Pacific Rim International Conference on Advanced Materials and Processing - the 8 th in the series of forums dedicated to advanced materials and processing - is being organized this year by TMS. The conference is jointly sponsored by CSM, JIM, MA, and KIM and rotates among these sponsoring organizations. PRICM-8 will include plenary, keynote, and contributed presentations on topics such as advanced steels and processing, bulk metallic glasses and nanomaterials, light metals and alloys, thin films and surface engineering, materials for energy, and many others. Contact: Meeting Services, TMS, 184 Thorn Hill Road, Warrendale, PA 15086; (724) 776-9000, ext. 243; fax: (724) 776-3770; e-mail:mtgserv@tms.org;www.tms .org/meetings/specialty/pricm8/home.aspx.

\section{TMS Go-sponsored Meetings}

Materials Challenges in Alternative \& Renewable Energy 2012: February 26-March 1, 2012; Clearwater, Florida; www.ceramics.org/mcare2012.

Offshore Technology Conference 2012 (OTC 2012): April 30-May 3, 2012; Houston, Texas; www.otcnet.org/2012.

Conference of Metallurgists - COM 2012: September 30-October 3, 2012, Niagara, ON; Canada; www.metsoc.org/com2012.asp. 